\title{
Performa dan Determinan Petani dalam Keputusan Adopsi Inovasi Sistem Tanam Padi Rawa di Sumatera Selatan
}

\author{
Performance and Determinants of Farmers in Adoption Decision of Innovation \\ for Swamps Rice Cropping System in South Sumatra
}

\author{
Dessy Adriani $^{1 *}$, Elisa Wildayana ${ }^{1}$, Idham Alamsyah ${ }^{1}$, Amruzie Minha $^{1}$ \\ ${ }^{1}$ Fakultas Pertanian Universitas Sriwijaya, Indralaya 30662 \\ ${ }^{*}$ Penulis untuk korespondensi: dessyadriani@fp.unsri.ac.id
}

(diterima 19 September 2019, disetujui 11 Oktober 2019)

Sitasi: Adriani D, Wildayana E, Alamsyah I, Minha A. 2019. Performance and determinants of farmers in adoption decision of innovation for swamps rice cropping system in South Sumatra. Jurnal Lahan Suboptimal: Journal of Suboptimal Lands. 8(2): 181-191.

\begin{abstract}
The development of food crops in swamplands became one of main focus of the government in the development of rice farming in Indonesia. A variety of ecological constraints that accompany the development of agriculture in swamp land overcome by a variety of technological innovations, one of which is with the application of Cropping Index 200 (CI 200) technology. After nearly 5 years of CI 200 technology applied on swamp land is considered necessary for analysis related to the performance of socioeconomic of farmers in the adoption of technology innovations CI 200. This study aimed to analyze the socio-economic condition of farmers in adopting IP 200 technology innovation, and analyze the determinants of IP 200 technology adoption decisions. Research was using the survey method and has been carried out in 2 districts, namely Tanjung Lago sub-District, Banyuasin District and Pemulutan sub-District, Ogan Ilir District in June-July 2019. Sampling method used disproportionate stratified random sampling. The analysis of the data was using tabulations, mathematical and logistic regression analysis. The results of the analysis showed that there were differences in the performance of the socioeconomy of farmers adopting and not adopting. The performance of the socio-economic of farmers who adopt were better than farmers who did not adopt the technology CI 200. The factors that determine the farmers adopt were the age, education, origin, experience, income, and the cost of farming.
\end{abstract}

Keywords: constraint, ecology, factors, swamplands, technology

\begin{abstract}
ABSTRAK
Pengembangan pertanian tanaman pangan di lahan rawa menjadi salah satu pusat perhatian pemerintah dalam pengembangan pertanian padi di Indonesia. Berbagai kendala ekologi yang menyertai pengembangan pertanian di lahan rawa di atasi dengan berbagai inovasi teknologi, salah satunya adalah dengan penerapan teknologi IP 200. Setelah hampir 5 tahun teknologi IP 200 diaplikasikan di lahan rawa dipandang perlu dilakukan analisis terkait dengan keragaan sosial ekonomi petani dalam adopsi inovasi teknologi IP 200. Penelitian ini bertujuan untuk menganalisis kondisi keragaan sosial ekonomi petani dalam adopsi inovasi teknologi IP 200, dan Menganalis faktor penentu keputusan adopsi teknologi IP 200. Penelitian menggunakan metode survey. Penelitian di dilaksanakan di 2
\end{abstract}


kabupaten yaitu Kabupaten Banyuasin, dengan mengambil Kecamatan Tanjung Lago sebagai lokasi pertanaman padi pasang surut, dan Kabupaten Ogan Ilir dengan mengambil kecamatan pemulutan sebagai lokasi pertanaman padi rawa lebak pada bulan Juni-Juli 2019. Metode pengambilan sampel adalah metode acak berlapis tak berimbang. Analisis data menggunakan tabulasi, matematis dan analisis regresi logistik. Hasil analisis menunjukkan terdapat perbedaan performa sosial-ekonomi petani yang mengadopsi dan tidak mengadopsi. Performa sosial-ekonomi petani yang mengadopsi lebih baik daripada petani yang tidak mengadopsi teknologi IP 200. Faktor yang menentukan petani mengadopsi adalah umur, pendidikan, asal, pengalaman, pendapatan, dan biaya usahatani.

Kata kunci: ekologi, kendala, faktor, rawa, teknologi

\section{PENDAHULUAN}

Persoalan keterbatasan lahan dan konversi lahan menyebabkan Indonesia tidak mempunyai pilihan lain dalam mewujudkan ketahanan pangan nasional, selain dengan memanfaatkan lahan suboptimal. Salah satu jenis lahan suboptimal yang dapat dimanfaatkan adalah lahan rawa. Lahan rawa di Indonesia menyebar di Sumatera, Kalimantan, dan Papua Barat. Di Sumetara, lahan rawa terluas berada di Sumatera Selatan. Hanya saja disayangkan, di tahap awal perkembangannya hanya sedikit areal lahan rawa yang dapat dioptimalkan untuk ditanami. Kendala tehnis-ekologis-agromis menjadi penyebab utamanya. Oleh kerenanya, aplikasi teknologi pertanian yang berkesuaian menjadi syarat keharusan untuk pengembangan pertanian di lahan rawa (Lakitan dan N. Gofar, 2013; Herwinita dan Hutapea, 2018).

Peranan lahan pasang surut dalam penyediaan beras dapat ditingkatkan melalui strategi peningkatan produktivitas dan indeks pertanaman, perluasan areal tanam, penggunaan varietas yang toleran, pengelolaan tata air, pemupukan, pengolahan tanah, pengendalian organisme pengganggu, serta didukung oleh perbaikan aspek sosial ekonomi petani (Alihamsyah et al., 2001; Irwandi, 2015). Sejak kurun waktu 2000-an hingga sekarang, pemerintah bekerjasama dengan perguruan tinggi dan lembaga peneliti secara intensif melaksanakan penelitian dan mengembangkan teknologi untuk pertanian pangan di lahan rawa (Imanudin and
Susanto. 2008; Masganti dan N. Yuliani, 2010; Suwignyo et al., 2010; Gofar N. et al., 2013). Pengembangan lahan rawa diprioritaskan tidak hanya pada perbaikan kondisi fisik lahan tetapi juga pada perbaikan pada system sosial kelembagaan.

Dari sisi sosial dan ekonomi, masih banyak petani yang mengalami kendala permodalan untuk membiayai usatahi tani, ketidakmampuan mengakses teknologi akibat rendahnya pendidikan, dan juga menurunnya minat untuk bekerja di sektor pertanian. Dengan demikian, untuk mewujudkan keberlanjutan pengelolaan lahan rawa, maka semua upaya teknis dan teknologis yang dilakukan harus pula mempertimbangkan kemungkinan dampak ekologisnya, kesesuaian sosiokultural dengan masyarakat lokal, selain tentunya menguntungkan secara ekonomi bagi petani sebagai pelaku utamanya (Lakitan, 2013; Lakitan dan Gofar, 2013). Pengembangan pertanian tanaman pangan di lahan rawa menjadi salah satu pusat perhatian pemerintah dalam pengembangan pertanian padi di Indonesia. Berbagai kendala ekologi yang menyertai pengembangan pertanian di lahan rawa di atasi dengan berbagai inovasi teknologi, salah satunya adalah dengan penerapan teknologi pertanian terpadu dengan indeks pertanaman (IP) 200. Salah satu program unggulan pemerintah di bidang pertanian adalah indeks pertanaman 200. Program ini awalnya di laksanakan di lokasi sawah irigasi. Keberhasilan program ini di areal irigasi menyebabkan program ini diperluas untuk wilayah lahan rawa sejak tahun 2013-2014 an. Pada Tahun 2007, pemerintah mencanangkan program 
yang disebut dengan program P2BN (Peningkatan Produksi Beras Nasional). Strategi Program adalah peningkatan produktivitas padi melalui aplikasi teknologi. Seperti telah disampaikan sebelumnya, bahwa Badan Litbang Pertanian bekerjasama dengan perguruan tinggi telah menghasilkan berbagai inovasi teknologi yang mampu mendorong produktivitas padi, diantaranye melalui penggunaan varietas unggul. Sejalan dengan perkembangan ilmu pengetahuan dan teknologi, Badan Litbang Pertanian juga telah menghasilkan dan mengembangkan pendekatan Pengelolaan Tanaman Terpadu (PTT) yang ternyata mampu meningkatkan produktivitas padi dan efisiensi input produksi (Badan Litbang Pertanian, 2010; Badan Litbang Pertanian, 2013).

Salah satu teknologi pengolaan tanaman terpadu (PTT) yang diunggulkan adalah perbaikan sistem tanam. Solusi teknologi adalah dengan sistem pompanisasi, dimana areal persawahan dibangun tanggul sekelilingnya guna mencegah jika terjadi banjir, sehingga air tidak membanjiri areal persawahan. Apabila musim kemarau (kering) dapat menggunakan pompanisasi untuk mengairi areal persawahan. Dengan demikian tata air sawah lebak dapat diatur sehingga dapat meningkatkan indek pertanaman menjadi IP 200 atau IP 300. Peningkatan indeks pertanaman (IP) 200 padi maksudnya meningkatkan intensitas penanaman padi dalam periode satu tahun (dalam pengertian 12 bulan), misalnya dari yang biasanya ditanam hanya satu kali oleh petani, ditingkatkan penanamannya menjadi 2 kali dalam satu tahun. Indeks pertanaman merupakan hasil perbandingan antara jumlah luas masing-masing jenis tanaman dalam pola tanam selama setahun dengan luas lahan yang tersedia untuk ditanami dikalikan 100. Lahan kering dan lahan sawah perlu dimanfaatkan secara maksimal dengan peningkatan IP, disamping intensifikasi budidaya dan konservasi sumberdaya pertanian. Peningkatan IP dapat diupayakan dengan cara mempersingkat proses produksi, meniadakan waktu lowong antara dua pertanaman, dan menumpang tindihkan dua pertanaman (Fadhly, 2009).

Sistem Tanam dengan IP 200 di lahan rawa terkait dengan 6 pengembangan pola tanam baru bagi petani. Beberapa faktor yang perlu diperhatikan dalam pengembangan pola tanam adaIah: ketersediaan air yang cukup mencakup waktu dan lama ketersediaan, keadaan tanah, tinggi tempat dari permukaan laut, eksistensi hama dan penyakit tanaman, ketersediaan dan aksesibilitas jenis dan varietas padi, aksesibilitas dan kelancaran hasil produksi, kemampuan permodalan petani, dan karakteristik pengembangannya (Badan Litbang Pertanian, 2010; 2013).

Program IP 200 ini masih terdapat kendala-kendala teknis yang bisa mengakibatkan resiko usahatani, maka oleh sebab itu perlu diketahui keputusan petani untuk mengadopsi IP 200 di lahan pertanian mereka seperti diungkap Rogers (2003); Efendy dan Hutapea (2010). Keputusan adopsi tentu saja berkaitan dengan rasionalitas sosial ekonomi petani. Rasionalitas sendiri merupakan sebuah keputusan yang rasional yang tidak hanya beralasan, tetapi juga optimal untuk mencapai suatu tujuan atau menyelesaikan masalah menurut Max Weber dalam Nuril (2011). Setelah hampir 5 tahun teknologi IP 200 diaplikasikan di lahan rawa dipandang perlu dilakukan analisis terkait dengan keragaan sosial ekonomi petani dalam adopsi inovasi teknologi IP 200 termasuk faktor penentu adopsinya. Dengan demikian, Penelitian ini bertujuan untuk menganalisis kondisi keragaan sosial ekonomi petani dalam adopsi inovasi teknologi IP 200, dan menganalis faktor penentu keputusan adopsi teknologi IP 200.

\section{BAHAN DAN METODE}

Penelitian menggunakan metode survey. Penelitian di dilaksanakan di 2 kabupaten yaitu Kecamatan Tanjung Lago, Kabupaten Banyuasin sebagai lokasi pertanaman padi 
pasang surut, dan Kecamatan Pemulutan Kabupaten Ogan Ilir sebagai lokasi pertanaman padi rawa lebak pada bulan Juni-Juli 2019. Setiap kecamatan diwakili oleh 1 desa yang didalamnya masih terdapat petani yang menerapkan dan tidak menerapkan IP 200. Metode pengambilan sampel adalah acak berlapis tak berimbang (disproportionated stratified random sampling). Total jumlah sampel 100 orang, dengan respondent rate berkisar $10 \%$.

Analisis data menggunakan tabulasi, matematis dan analisis regresi logistik. Perfoma petani yang mengadopsi dan tidak mengadopsi ditunjukkan oleh variabel sistematis sehingga diperoleh hasil yang lengkap dan terperinci yaitu asal petani, umur, pendidikan, pengalaman UT, jumlah anggota keluarga, saluran komunikasi, ciri sistem sosial, keaktifan dalam kelompok tani, frekuensi penyuluh, motivasi, produksi, produktifitas, biaya produksi, biaya, penerimaan, pendapatan usaha tani, harga jual, resiko usaha tani. Selanjutnya untuk menganalisis faktor-faktor yang mempengaruhi keputusan petani mengadopsi digunakan persamaan logistik sebagai berikut:

$\mathrm{K}=\operatorname{Ln}(\mathrm{P} / 1-\mathrm{P})=\alpha+\beta_{1} \mathrm{LnU}+\beta_{2} \operatorname{LnP}+$ $\beta_{3} \mathrm{LnD}_{1}+\beta_{4} \mathrm{LnPU}+\beta_{5} \mathrm{LnJAK}+\beta_{6} \operatorname{LnPdP}+$ $\beta_{7} \mathrm{LnD}_{2}+\beta_{8} \mathrm{LnBU}+\beta_{9} \mathrm{LnFP}+$ e............................ (1)

Dimana:

$\mathrm{P} \quad=$ Peluang petani untuk mengadopsi

$1-\mathrm{P}=$ Peluang petani untuk tidak mengadopsi

$\alpha \quad=$ Intersep

$\beta_{1-11}=$ Koefisien Regresi

$\mathrm{U} \quad=$ Umur petani (tahun)

$\mathrm{P} \quad=$ Pendidikan petani (tahun)

$\mathrm{D}_{1} \quad=$ Asal Petani (1 jika petani lokal, 0 jika petani pendatang)

PU =Pengalaman Usahatani (thn)

JAK =Jumlah Anggota Keluarga (orang)

PdP =Pendapatan Usahatani Padi (Rp)

$\mathrm{D}_{2} \quad=$ Sumber Modal (1 jika milik sendiri, 0 jika lainnya)

BU =Biaya usahatani Padi (Rp)
FP =Frekuensi Penyuluhan (kali/thn)

e $\quad=$ Galat atau pengganggu

Untuk memastikan bahwa model yang dihasilkan memenuhi kriteria Goodness of Fit dan tidak mengalami pelanggaran asumsi klasik, maka dilakukan juga pengujian multikolinieritas, heteroskedastisitas, dan autokorelasi.

\section{HASIL}

\section{Performa Petani dalam Adopsi Inovasi Padi Rawa IP 200 di Sumatera Selatan}

Hasil analisis menunjukkan terdapat perbedaan performa sosial-ekonomi petani yang mengadopsi dan tidak mengadopsi. Performa sosial-ekonomi petani yang mengadopsi lebih baik daripada petani yang tidak mengadopsi teknologi IP 200. Tabel 1 menunjukkan dari sisi usia, petani yang mengadopsi IP 200 didominasi oleh penduduk usia muda (20-30 tahun), sebaliknya untuk petani yang tidak mengadopsi didominasi oleh penduduk usia di atas 30 tahun.

Selanjutnya dari sisi pendidikan, petani yang mengadopsi IP 200 didominasi oleh penduduk terdidik (41,93\% tamat SMA), sementara untuk petani yang tidak mengadopsi didominasi oleh penduduk yang tidak tamat/tamat SD. Searah dengan usia, penduduk, petani yang mengadopsi IP 200 didominasi oleh penduduk dengan pengalaman usahatani hanya 2-12 tahun $(61,29 \%)$, sementara untuk petani yang tidak mengadopsi didominasi oleh penduduk dengan pengalaman usahatani lebih dari 12 tahun. Dari sisi asal, petani yang mengadopsi IP 200 didominasi oleh penduduk pendatang $(90,32 \%)$, sebaliknya untuk petani yang tidak mengadopsi didominasi oleh penduduk local $(93,33 \%)$.

Sumber modal petani penerap sebagian besar $(74,19 \%)$ berasal dari modal campuran (pribadi dan pinjaman), sementara sumber modal petani non penerap berasal dari modal sendiri $(57,14)$. Sumber informasi petani penerap sudah 
mulai lebih bervariasi tidak hanya mengandalkan televisi, tetapi juga sudah mulai menggunakan koran dan bahkan brosur. Hal menarik yang ditemukan dalam penelitian ini adalah perkembangan system sosial yang berkembang di kedua komunitas. Sistem sosial petani penerap memiliki ciri modern, sementara system sosial untuk petani non penerap masih bersifat tradisional. Jika hanya dinilai sisi performa (Tabel 1), maka dapat dipahami bahwa performa petani penerap lebih baik daripada petani non penerap. Namun penilaian dari sisi performa sosial tidak cukup, temuan menarik terkait dengan performa ekonomi petani (Tabel 2). Hasil perhitungan menunjukkan bahwa pendapatan petani penarap lebih tinggi daripada petani non penerap. Namun indikasi lebih tingginya pendapatan ini harus dipahami secara hati hati karena nilai $\mathrm{R} / \mathrm{C}$ dan $\mathrm{B} / \mathrm{C}$ menunjukkan hasil yang tidak berbeda.

\section{Determinan Petani dalam Adopsi Inovasi Padi Rawa IP 200 di Sumatera Selatan}

Hasil analisis dengan menggunakan persamaan regresi logistic untuk menentukan determinan petani dalam melakukan adopsi (Tabel 3). Untuk memastikan model yang dihasilkan memenuhi kriteria Goodness of Fit dan tidak mengalami pelanggaran asumsi klasik, maka dilakukan pengujian multikolinieritas, heteroskedastisitas, dan autokorelasi. Hasil pengujian menunjukkan bahwa nilai koefisien determinasi yang diperoleh sebesar 0,839. Hal ini menunjukkan bahwa 83,9 persen variabel bebas yaitu faktor sosial, ekonomi dan situasional dapat menjelaskan varibel keputusan petani untuk mengadopsi secara bersama-sama, sedangkan 16,1 persen dijelaskan oleh faktor lain yang tidak termasuk dalam model penelitian ini. Hasil pengujian asumsi klasik juga menunjukkan model yang dikembangkan tidak mengalami masalah multikorieritas dengan nilai VIF <10 dan tidak mengalami autokorelasi juga heteroskedastisitas dimana nilai $\alpha$-hitung hasil pengujian heretoskedastisitas lebih besar dari 0,05. Hasil analisis juga menunjukkan faktor yang menentukan petani mengadopsi adalah umur, pendidikan, asal, pendapatan, dan biaya usahatani.

\section{PEMBAHASAN}

\section{Performa Petani dalam Adopsi Inovasi Sistem Tanam Padi Rawa IP 200 di Sumatera Selatan}

Pengembangan inovasi system tanam IP 200 di lahan rawa Provinsi Sumatera Selatan mulai dijalani tahun 2013. Untuk wilayah rawa, kegiatan ini banyak dikembangkan di wilayah lahan rawa lebak dan rawa pasang surut. Dalam perkembangannya, program ini mengalami banyak kendala. Kendala yang dihadapi tidak hanya kendala ekologi tetapi juga sosial, ekonomi dan budaya. Perubahan system tanam yang awalnya hanya 1 kali setahun menjadi 2-3 kali setahun mensyaratkan perlunya perubahan sosial, ekonomi dan budaya yang menyertai. Teknologi perubahan sistem tanam ini memungkinkan dilakukan seperti diungkap juga oleh Maftu'ah et al., 2016. Setelah program inovasi system tanam IP 200 dilaksanakan hampir 5 tahun, maka perlu kembali dilakukan penelitian terkait dengan gambaran/keragaan/performa petani saat ini baik petani yang sudah menerapkan maupun yang tidak menerapkan. Penelitian ini penting dilakukan untuk memberikan arah dalam penyusunan kebijakan terkait dengan peningkatan produktifitas padi dan akhirnya pada peningkatan kesejahteraan petani.

Tabel 1 menunjukkan bahwa petani penerap adalah petani yang didominasi oleh usia yang lebih muda dan kondisi pendidikan lebih baik daripada petani yang mengadopsi. Dari sisi asal petani, petani penerap rata-rata adalah petani pendatang, dengan usia pengalaman usaha tani relatif muda. Hasil ini menunjukkan bahwa petani yang berusia muda, baru melaksanakan usahatani, pendidikan lebih baik, dan 
pendatang memiliki motivasi yang lebih baik untuk mengadopsi inovasi teknologi daripada petani yang usianya lebih tua, tidak berpendidikan, dan berasal dari penduduk lokal. Hasil penelitian ini sejalan dengan penelitian Burhansyah (2014) dan Setiawan dan Astini (2017).

Dari sisi kondisi sosial ditemukan beberapa temuan menarik. Petani penerap lebih sering mendapat penyuluhan dan lebih aktif dalam kelompok tani daripada petani non penerap. Kelompok tani penerap lebih terbuka terhadap informasi. Ketika digali lebih dalam, jarangnya petani non penerap mendapatkan penyuluhan lebih karena persoalan personal yaitu merasa sudah nyaman dengan system tanam IP 100. Petani non penerap juga biasanya memiliki kegiatan non pertanian lainnya, misalnya memiliki usaha perkebunan sawit atau karet, warung, dan juga peternakan. Sementara, petani penerap rata-rata mengandalkan hidupnya hanya dari usahatani padi. Dari sisi perkembangan ciri system sosial, petani penerap memiliki system modern, sementara petanin non penerap didominasi oleh system tradisional. Media komunikasi yang digunakan untuk memperolah informasi juga berbeda di antara kedua kelompok. Petani penerap tidak hanya mengandalkan radio dan televisi, tetapi penggunaan Koran dan brosur juga sudah banyak digunakan. Selanjutnya, dari sisi motivasi, petani penerap memiliki motivasi lebih tinggi daripada penatni penerap seperti yang ditemukan oleh Setiawan dan Astini (2017).

Dari sisi ekonomi, petani penerap lebih banyak menggunakan sumber modal campuran (modal sendiri dan pinjaman), sementara petanin non penerap lebih banyak menggunakan modal sendiri. Namun, hasil penelitian ini menemukan tidak adak perbedaan performa dari sisi jumlah anggota keluarga, tingkat resiko usahatani, dan luas lahan. Dengan demikian, ketiga variable tersebut diduga tidak berpengaruh terhadap keputusan untuk menerapkan adopsi inovasi.
Selanjutnya Tabel 2 menyajikan mengenai capaian keberhasilan usahatani bagi petani dalam adopsi Inovasi Padi Rawa IP 200. Hasil perhitungan secara finansial menunjukkan bahwa petani yang menerapkan adopsi Inovasi Padi Rawa IP 200 memperoleh pendapatan yang lebih tinggi yaitu $\mathrm{Rp} 29.724 .349,70$ /ha/tahun dibandingkan dengan non penerap $\mathrm{Rp}$ 15.355.649,61 /ha/tahun. Dengan demikian, pendapatan penerap meningkat 2 kali lipat pertahunnya, dengan keuntungan relative 1,93 .

Namun, kita perlu pula hati hati membaca nilai tersebut, karena jika dinilai dari kriteria $\mathrm{R} / \mathrm{C}$ dan $\mathrm{B} / \mathrm{C}$, hasil uji beda nilai tengah menunjukkan bahwa tidak ada perbedaan dari capaian $\mathrm{R} / \mathrm{C}$ dan $\mathrm{B} / \mathrm{C}$. Dengan demikian, capaian usahatani sebenernya sama untuk penerap dan non penerap. Hasil ini sesuai dengan Hutapea et al., (2013) yang menyatakan bahwa nilai $\mathrm{R} / \mathrm{C}$ petani kedelai yang menerapkan 1-2 kali musin tanam (R/C 1,58) dengan 3-4 kali musin tanam $(\mathrm{R} / \mathrm{C} 1,53)$ tidak berbeda secara statistik. Perbedaan nilai efisiensi $\mathrm{R} / \mathrm{C}$ baru terlihat saat petani menerapkan 56 kali musin tanaman setahun.

\section{Determinan Petani dalam Adopsi Inovasi Sistem Tanam Padi Rawa IP 200 di Sumatera Selatan}

Tabel 3 menyajikan hasil analisis regresi logistic determinan petani dalam adopsi inovasi padi rawa IP 200 di Sumatera Selatan. Nilai koefisien determinasi (Nagelkerke $R^{2}$ ) sebesar 0,839. Hal ini menunjukkan bahwa 83,9 persen variabel bebas dapat menjelaskan varibel keputusan petani untuk mengadopsi, sedangkan 16,1 persen dijelaskan oleh faktor lain yang tidak termasuk dalam model penelitian ini. Persamaan regresi tersebut menjelaskan bahwa faktor umur petani dan biaya produksi berpengaruh negatif terhadap produksi padi yang menerapkan IP 200. Sedangkan faktor pendidikan,asal petani, pengalaman usahatani, jumlah anggota keluarga, sumber modal, pendapatan padi, dan frekuensi penyuluhan berpengaruh 
positif terhadap produksi padi petani yang menerapkan IP 200. Dengan demikian, determinan keputusan adopsi petani pendidikan, asal petani, pengalaman usahatani, jumlah anggota keluarga, sumber modal, pendapatan padi, dan frekuensi penyuluhan. Hasil ini sejalan dengan penelitian Faizaty et al., .2016. Hasil persamaan regresi logistic merupakan persamaan yang digunakan dalam pengambilan keputusan. Dalam penelitian ini, persamaan regresi logistic digunakan untuk menganalisi peluang petani untuk mengadopsi atau tidak mengadopsi, yang ditunjukkan oleh nilai Odds Ratio (Tabel $3)$.

Dari sisi kondisi sosial ditemukan beberapa temuan menarik. Petani penerap lebih sering mendapat penyuluhan dan lebih aktif dalam kelompok tani daripada petani non penerap. Kelompok tani penerap lebih terbuka terhadap informasi. Ketika digali lebih dalam, jarangnya petani non penerap mendapatkan penyuluhan lebih karena persoalan personal yaitu merasa sudah nyaman dengan system tanam IP 100. Petani non penerap juga biasanya memiliki kegiatan non pertanian lainnya, misalnya memiliki usaha perkebunan sawit atau karet, warung, dan juga peternakan. Sementara, petani penerap rata-rata mengandalkan hidupnya hanya dari usahatani padi. Dari sisi perkembangan ciri system sosial, petani penerap memiliki system modern, sementara petanin non penerap didominasi oleh system tradisional. Media komunikasi yang digunakan untuk memperolah informasi juga berbeda di antara kedua kelompok. Petani penerap tidak hanya mengandalkan radio dan televisi, tetapi penggunaan Koran dan brosur juga sudah banyak digunakan. Selanjutnya, dari sisi motivasi, petani penerap memiliki motivasi lebih tinggi daripada penatni penerap seperti yang ditemukan oleh Setiawan dan Astini (2017).

Dari sisi ekonomi, petani penerap lebih banyak menggunakan sumber modal campuran (modal sendiri dan pinjaman), sementara petanin non penerap lebih banyak menggunakan modal sendiri. Namun, hasil penelitian ini menemukan tidak adak perbedaan performa dari sisi jumlah anggota keluarga, tingkat resiko usahatani, dan luas lahan. Dengan demikian, ketiga variable tersebut diduga tidak berpengaruh terhadap keputusan untuk menerapkan adopsi inovasi.

Selanjutnya Tabel 2 menyajikan mengenai capaian keberhasilan usahatani bagi petani dalam adopsi Inovasi Padi Rawa IP 200. Hasil perhitungan secara finansial menunjukkan bahwa petani yang menerapkan adopsi Inovasi Padi Rawa IP 200 memperoleh pendapatan yang lebih tinggi yaitu $\mathrm{Rp} 29.724 .349,70$ /ha/tahun dibandingkan dengan non penerap Rp 15.355.649,61 /ha/tahun. Dengan demikian, pendapatan penerap meningkat 2 kali lipat pertahunnya, dengan keuntungan relative 1,93 .

Namun, kita perlu pula hati hati membaca nilai tersebut, karena jika dinilai dari kriteria $\mathrm{R} / \mathrm{C}$ dan $\mathrm{B} / \mathrm{C}$, hasil uji beda nilai tengah menunjukkan bahwa tidak ada perbedaan dari capaian $\mathrm{R} / \mathrm{C}$ dan $\mathrm{B} / \mathrm{C}$. Dengan demikian, capaian usahatani sebenernya sama untuk penerap dan non penerap. Hasil ini sesuai dengan Hutapea et al., (2013) yang menyatakan bahwa nilai $\mathrm{R} / \mathrm{C}$ petani kedelai yang menerapkan 1-2 kali musin tanam (R/C 1,58) dengan 3-4 kali musin tanam (R/C 1,53) tidak berbeda secara statistik. Perbedaan nilai efisiensi $\mathrm{R} / \mathrm{C}$ baru terlihat saat petani menerapkan 56 kali musin tanaman setahun.

\section{Determinan Petani dalam Adopsi Inovasi Sistem Tanam Padi Rawa IP 200 di Sumatera Selatan}

Tabel 3 menyajikan hasil analisis regresi logistic determinan petani dalam adopsi inovasi padi rawa IP 200 di Sumatera Selatan. Nilai koefisien determinasi (Nagelkerke $R^{2}$ ) sebesar 0,839 . Hal ini menunjukkan bahwa 83,9 persen variabel bebas dapat menjelaskan varibel keputusan petani untuk mengadopsi, sedangkan 16,1 persen dijelaskan oleh faktor lain yang tidak termasuk dalam model penelitian ini. 
Tabel 1. Performa sosial petani penerap dan non penerap IP 200 di lahan rawa provinsi Sumatera Selatan, 2019

\begin{tabular}{|c|c|c|}
\hline Variabel & Petani Penerap $(\%) \mathrm{N}=50$ & Petani Non Penerap (\%) $\mathrm{N}=50$ \\
\hline \multicolumn{3}{|l|}{ Umur Petani (Tahun) } \\
\hline - $20-30$ & 38,71 & 0,00 \\
\hline - $31-40$ & 25,81 & 14,29 \\
\hline - $41-50$ & 25,81 & 14,29 \\
\hline$\cdot>50$ & 9,67 & 71,42 \\
\hline \multicolumn{3}{|l|}{ Pendidikan (Tahun) } \\
\hline - Tidak/Tamat SD & 22,58 & 100,00 \\
\hline - Tamat SMP & 35,49 & 0 \\
\hline - Tamat SMA & 41,93 & 0 \\
\hline \multicolumn{3}{|l|}{ Asal Petani } \\
\hline - Lokal & 9,68 & 93,33 \\
\hline - $\quad$ Pendatang & 90,32 & 6,67 \\
\hline \multicolumn{3}{|c|}{ Pengalaman Usahatani (Tahun) } \\
\hline - 2-12 & 61,29 & 14,28 \\
\hline - $13-23$ & 25,80 & 57,15 \\
\hline - $24-34$ & 9,68 & 0 \\
\hline - $\quad 35-45$ & 3,23 & 0 \\
\hline - $46-56$ & 0 & 28,57 \\
\hline \multicolumn{3}{|c|}{ Jumlah Anggota keluarga (Orang) } \\
\hline - $1-2$ & 6,46 & 14,28 \\
\hline - $3-4$ & 38,70 & 57,16 \\
\hline - $5-6$ & 35,49 & 14,28 \\
\hline - $7-8$ & 16,12 & 14,28 \\
\hline - $\quad 9-10$ & 3,23 & 0 \\
\hline \multicolumn{3}{|l|}{ Sumber Modal (\%) } \\
\hline - $\quad$ Milik Sendiri & 25,81 & 57,14 \\
\hline - Campuran & 74,19 & 42,86 \\
\hline \multicolumn{3}{|l|}{ Frekwensi Penyuluhan } \\
\hline - $\quad$ Tidak pernah-1 & 0,00 & 78,00 \\
\hline - $\quad 2-3$ & 19,35 & 22,00 \\
\hline - $4-5$ & 41,94 & 0 \\
\hline - $6-7$ & 22,58 & 0 \\
\hline - $8-9$ & 16,13 & 0 \\
\hline \multicolumn{3}{|c|}{ Keaktifan Dalam Kelompok Tani } \\
\hline - Aktif & 66,67 & 50,00 \\
\hline - $\quad$ Tidak Aktif & 33,33 & 50,00 \\
\hline \multicolumn{3}{|c|}{ Media Komunikasi yang Paling } \\
\hline \multicolumn{3}{|c|}{ Banyak Digunakan } \\
\hline $\begin{array}{ll}\text { - } & \text { Radio } \\
\text { - } & \text { Televisi }\end{array}$ & 75,30 & 80,12 \\
\hline $\begin{array}{ll}\bullet & \text { Televis1 } \\
\text { - } & \text { Koran }\end{array}$ & 11,49 & 6,11 \\
\hline - Brosur & 8,11 & 5.41 \\
\hline \multicolumn{3}{|l|}{ Ciri Sistem Sosial } \\
\hline - $\quad$ Modern & 66,67 & 0,00 \\
\hline - $\quad$ Tradisional & 33,33 & 100,00 \\
\hline \multicolumn{3}{|l|}{ Motivasi } \\
\hline - $\quad$ Motivasi Tinggi & 83,33 & 0,00 \\
\hline - Motivasi Rendah & 16,67 & 100,00 \\
\hline Tingkat Resiko & 39,56 & 40,10 \\
\hline \multicolumn{3}{|l|}{ Luas Lahan } \\
\hline - $\quad 0,5-1,0 \mathrm{Ha}$ & 60,00 & 66,67 \\
\hline - $\quad 1,1-2,0 \mathrm{Ha}$ & 40,00 & 33,33 \\
\hline
\end{tabular}


Persamaan regresi tersebut menjelaskan bahwa faktor umur petani dan biaya produksi berpengaruh negatif terhadap produksi padi yang menerapkan IP 200. Sedangkan faktor pendidikan,asal petani, pengalaman usahatani, jumlah anggota keluarga, sumber modal, pendapatan padi, dan frekuensi penyuluhan berpengaruh positif terhadap produksi padi petani yang menerapkan IP 200. Dengan demikian, determinan keputusan adopsi petani pendidikan,asal petani, pengalaman usahatani, jumlah anggota keluarga, sumber modal, pendapatan padi, dan frekuensi penyuluhan. Hasil ini sejalan dengan penelitian Faizaty et al., .2016. Hasil persamaan regresi logistic merupakan persamaan yang digunakan dalam pengambilan keputusan. Dalam penelitian ini, persamaan regresi logistic digunakan untuk menganalisi peluang petani untuk mengadopsi atau tidak mengadopsi, yang ditunjukkan oleh nilai Odds Ratio (Tabel $3)$.

Tabel 2. Performa ekonomi usahatani dalam adopsi inovasi padi rawa IP 200 di Sumatera Selatan, 2019

\begin{tabular}{lccc}
\hline Variabel & $\begin{array}{c}\text { Petani Penerap (\%) } \\
\mathrm{N}=50\end{array}$ & $\begin{array}{c}\text { Petani Non Penerap (\%) } \\
\text { N=50 }\end{array}$ & $\begin{array}{c}\text { Signifikansi } \\
\text { Uji-t }\end{array}$ \\
\hline Biaya Produksi (Rp/ha/Thn) & $7.126 .497,01$ & $3.636 .750,39$ & - \\
Penerimaan (Rp/ha/Thn) & $36.850 .846,67$ & $18.992 .400,00$ & - \\
Pendapatan (Rp/ha/Thn) & $29.724 .349,70$ & $15.355 .649,61$ & $0,187^{*}$ \\
R/C & 5,17 & 5,22 & $0,190 *$ \\
B/C & 4,17 & 4,22 & - \\
Keuntungan Relatif & & 1,93 & - \\
\hline
\end{tabular}

Keterangan: * Tidak berbeda nyata pada $\alpha=0.05$

Tabel 3. Hasil analisis regresi logistik determinan petani dalam adopsi inovasi padi rawa IP 200 di Sumatera Selatan, 2019

\begin{tabular}{|c|c|c|c|c|}
\hline Variabel & Koefisien & Wald & Taraf Nyata & Odds Ratio \\
\hline Intersep & 0,460 & 0,681 & 0,503 & \\
\hline Umur & $-0,025$ & $-2,457$ & $0,023^{*}$ & 0,98 \\
\hline Pendidikan & 0,107 & 2,007 & $0,050 *$ & 0,90 \\
\hline Asal Petani & 0,709 & 1,736 & $0,097 * *$ & 2,03 \\
\hline Pengalaman Usahatani & 0,019 & 1,491 & 0,141 & 1,02 \\
\hline Jumlah Anggota Keluarga & 0,018 & 0,279 & 0,783 & 1,03 \\
\hline Sumber Modal & 0,268 & 1,337 & 0,196 & 1,31 \\
\hline Pendapatan & 2,420 & 8,649 & $0,000 *$ & 11,16 \\
\hline Biaya Usahatani & $-2,802$ & $-4,527$ & $0,000 *$ & 16,34 \\
\hline Frekuensi Penyuluhan & 0,028 & 0,602 & 0,554 & 1,03 \\
\hline
\end{tabular}

Nagelkerke $R^{2}=0,839 \quad \lambda^{2}=14,906$ signifikan pada $\alpha=0,050$

Keterangan: * Signifikasi pada $\alpha: 0,05, * *$ Signifikasi pada $\alpha: 0,10$

Variabel pertama yang berpengaruh terhadap keputusan adopsi adalah umur dan pendidikan dengan nilai oods ratio masing masing 0.98 dan 0.90, atau mendekati 1 . Dengan kata lain, jika umur meningkat satu tahun, maka peluang adopsi menurun 1 kali, sebaliknya jika pengalaman meningkat satu tahun, maka peluang adopsi meningkat satu kali. Hasil ini sesuai dengan hasil penelitian Burhansyah (2014) dimana umur dan pengalaman berkorelasi dengan kecepatan adopsi inovasi.

Nilai odds ratio yang ditunjukkan oleh variabel biaya usahatani sebesar 16,34.
Nilai ini berarti jika terjadi peningkatan biaya produksi sebesar 1 persen, maka peluang adopsi akan menurun sebesar 16, 34 kali. Nilai ini didukung oleh peroleh nilai odds ratio untuk variabel pendapatan sebesar 11,16. Hal ini berarti jika pendapatan meningkat sebesar $1 \%$, maka peluang petani mengadopsi meningkat sebesar 11,16 kali. Hal ini menunjukkan keputusan adopsi sangat dipengaruhi oleh biaya dan pendapatan usahatani seperti yang diungkap oleh Hutapea et al. (2013). Hasil analisis performa ekonomi (Tabel 2) menunjukkan bahwa petani yang menerapkan adopsi teknologi memperoleh 
peningkatan pendapatan 2 kali lebih tinggi daripada non penerap. Selanjutnya, asal petani juga memiliki peluang besar sebagai penentu petani menerapkan IP 200. Nilai odds ratio sebesar 2,03, nilai ini berarti peluang petani pendatang menerapkan IP 200 lebih tinggi 2,03 kali dibandingkan dengan petani lokal. Hasil penelitian ini searah dengan Slamet et al. (2013), bahwa tingkat adopsi petani lokal Lampung lebih rendah daripada petani pendatang asal Jawa dan Bali.

\section{KESIMPULAN}

Terdapat perbedaan performa sosialekonomi petani yang mengadopsi dan tidak mengadopsi. Performa sosial-ekonomi petani yang mengadopsi lebih baik daripada petani yang tidak mengadopsi teknologi IP 200. Petani yang menerapkan adopsi inovasi Padi Rawa IP 200 memperoleh pendapatan yang lebih tinggi yaitu Rp 29.724.349,70/ha/tahun dibandingkan dengan non penerap Rp 15.355.649,61/ha/tahun. Dengan demikian, pendapatan penerap meningkat 2 kali lipat pertahunnya, dengan keuntungan relatif 1,93. Namun jika dinilai dari kriteria $\mathrm{R} / \mathrm{C}$ dan B/C, hasil uji beda nilai tengah menunjukkan bahwa tidak ada perbedaan dari capaian R/C dan B/C. Persamaan regresi logistik menjelaskan bahwa faktor umur petani dan biaya produksi berpengaruh nyata negatif terhadap produksi padi yang menerapkan IP 200. Sedangkan faktor pendidikan, asal petani, pengalaman usahatani, dan pendapatan padi berpengaruh nyata positif terhadap produksi padi petani yang menerapkan IP 200. Peluang keputusan adopsi sangat ditentukan oleh biaya dan pendapatan usahatani.

\section{UCAPAN TERIMA KASIH}

Ucapan terimakasih disampaikan kepada pimpinan Universitas Sriwijaya dan Lembaga Penelitian dan Pengabdian pada Masyarakat Universitas Sriwijaya yang telah mendanai penelitian ini melalui
Skema Penelitian Hibah Kompetitif Tahun 2019.

\section{DAFTAR PUSTAKA}

Alihamsyah T, Sarwani M, Prayudi B. 2001. Penelitian dan pengembangan pertanian di Lahan Pasang Surut. di dalam: Sarda, D. K., Masganti, dan M. Sarwani (Eds), Prosiding Sosialisasi Hasil-hasil Penelitian dan Pengkajian Teknologi Pertanian Kalimantan Tengah. Balitbangtan PSEKP; Bogor, 1 Mei 2001. p 56-60.

Badan Penelitian dan Pengembangan Pertanian. 2010. Pengelolaan Tanaman Terpadu (PTT) Padi Lahan Rawa Lebak. Departemen Pertanian. Jakarta

Badan Penelitian dan Pengembangan Pertanian. 2013. Strategi Pengembangan Model PTT Padi Lahan Rawa Lebak. Jakarta: Kementerian Pertanian.

Balai Pengkajian Teknologi Pertanian Provinsi Sumatera Selatan. 2010. Potensi Lahan Rawa Lebak. Palembang: Balai Pengkajian Teknologi Pertanian Provinsi Sumatera Selatan.

Burhansyah, Rusli. 2014. Faktor-faktor yang mempengaruhi adopsi inovasi pertanian pada gapoktan puap dan non puap di Kalimantan Barat (Studi Kasus: Kabupaten Pontianak dan Landak). Jurnal Informatika Pertanian. 23(1): 6574.

Efendy J, Hutapea Y. 2010. Analisis Adopsi Inovasi Teknologi Pertanian Berbasis Padi di Sumatera Selatan dalam Perspektif Komunikasi. Jurnal Pengkajian dan Pengembangan Teknologi Pertanian. 13 (2):119-130.

Fadhly AF. 2009. Teknologi peningkatan indeks pertanaman jagung. Jakarta: Balai Penelitian Tanaman Serealia.

Faizaty NE, Rifin A, Tinaprilla N. 2016. Proses Pengambilan Keputusan Adopsi Inovasi Teknologi Budidaya Kedelai Jenuh Air (Kasus: Labuhan Ratu Enam, Lampung Timur). AGRARIS: Journal of Agribusiness and Rural Development Research. 2(2): 97-106. 
Gofar N, Widjajanti H, Ratmini NLPS. 2013. Pengembangan teknologi pupuk mikroba multiguna untuk meningkatkan produktivitas lahan rawa lebak. Laporan Penelitian SINas Kemenristek. Palembang: PUR-PLSO.

Herwinita, Hutapea Y. 2018. Swamp land optimization in supporting food security and enhancing farmers welfare in South Sumatra Indonesia. International Conference on Agriculture, Environment, and Food Security. IOP Conf. Series: Earth and Environmental Science 122012072 doi :10.1088/17551315/122/1/012072.

Hutapea, Yance, Suparwoto, Efendy J. 2013. Kecepatan adopsi varietas unggul dan kelayakan usahatani kedelai di Sumatera Selatan. Jurnal Agroekonomika. 2(2): 123-138.

Imanudin MS, Susanto RH. 2008. Perbaikan sarana infrastruktur jaringan tata air pada berbagai tipologi lahan rawa pasang surut Sumatera Selatan. Prosiding Seminar Nasional Rawa (Banjarmasin, 4 Agustus 2008). ISBN : 979985718-7.

Irwandi, Dedi. 2015. Strategi peningkatan pemanfaatan lahan rawa pasang surut dalam mendukung peningkatan produksi beras di Kalimantan Tengah. Jurnal Agroekonomika. 4 (1): 96-123.

Lakitan B. 2013. Connecting all the dots: Identifying the "Actor Level" challenges in establishing effective innovation system in Indonesia. Technology in Society. (1): 41-54.

Lakitan B, Gofar N. 2013. Kebijakan inovasi teknologi untuk pengelolaan lahan suboptimal berkelanjutan. Di dalam: Herlinda et al., (Eds). Prosiding Seminar Nasional Intensifikasi Pengelolaan Lahan Suboptimal dalam
Rangka Mendukung Kemandirian Pangan Nasional; Palembang, 20-21 September 2013. p 5-14.

Maftu'ah E, Annisa W, Noor M. 2016. Teknologi Pengelolaan Lahan Rawa untuk Tanaman Pangan dan Hortikultura dalam Konteks Adaptasi terhadap Perubahan Iklim. Jurnal Sumberdaya Lahan. 10(2): 103-114.

Masganti, Yuliani N. 2010. Produktivitas padi lokal di lahan pasang surut. Banjarmasin: Balai Pengkajian Teknologi Pertanian Kalimantan Tengah.

Nuril. 2011. Penjelasan Teori Sosiologi Max Weber: Rasionalitas dan Tindakan Sosial. Surabaya: Institut Agama Islam Negeri Sunan Ampel.

Rogers EM. 2003. Diffusion of Innovations, 5th ed. New York: Free Press. A Division of Macmillan Publishing Co Inc.

Setiawan, Dera I Gd B, Astiti, Sri NW. 2017. Faktor-Faktor yang mempengaruhi adopsi inovasi sistem tanam jajar legowo 2: 1 di subak penyaringan, Kecamatan Mendoyo, Kabupaten Jembrana. Jurnal Manajemen Agribisnis. 5(2): 1-6.

Slamet, Hariyadi FT, Subejo. 2013. Pengaruh adopsi inovasi pengelolaan tanaman terpadu padi sawah terhadap usahatani padi beberapa komunitas petani di Lampung. Jurnal Agribis. 3 (1): 49-63.

Suwignyo RA, Suharsono, Hasmeda M, Halimi ES, Kurnianingsih A. 2010. Pengembangan strategi pengelolaan budidaya padi rawa lebak dan perakitan varietas tahan rendaman berbahan genetik lokal. Laporan Hasil Penelitian Program Insentif Riset Terapan. Jakarta: Kementrian Negara Riset dan Teknologi. 